\title{
Könyvismertetés
}

\section{Papp-Váry Árpád (2019): Országmárkázás, Akadémiai Kiadó, Budpaest}

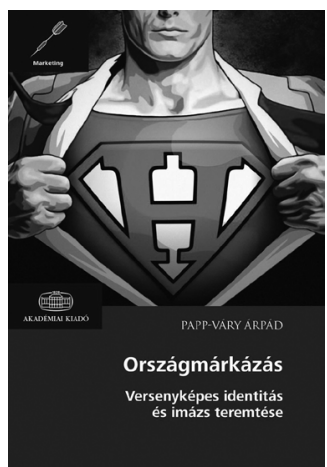

Az országmárkázás (country branding) voltaképp a márkázás (branding) alkalmazása egy speciális termékre, az országra. Az országok és más kisebb-nagyobb földrajzi egységek, illetve azok lakosai tulajdonképpen mindig is végeztek helymarketing tevékenységet; hol a turistákat szerették volna vonzani, hol a befektetőket, a telepeseket vagy a dolgozni vágyókat, hol pedig „,csak” jobb reputációt kívántak kialakítani a terület jobb érvényesülése végett, akár a külpiacon (a külpiacokra vezetett termékek kapcsán) vagy a külkapcsolatok terén (akár az országok közti gazdasági vagy politikai kapcsolatok miatt). Mindezekkel persze a cél mindig is az volt, hogy végsősoron valamiféle profitot generáljanak - tehát, mai szakszóval élve, versenyképesek legyenek. Versenyképesnek lenni pedig, a 21. században, nagyobb kihívás, mint valaha.

A gyakorlat persze idővel jó és rossz példák sorát hozta, amellyel az ösztön mellé kialakult a tudatosság is, hiszen a gyakorlati szakemberek mellett egyre több oktató és kutató kezdett el foglalkozni a helymarketinggel, sőt, a kihívások egyre több hallgatói munkát eredményeznek a mindennapi felsőoktatásban is. Mindezeknek nyújt nélkülözhetetlen segítséget Papp-Váry Árpád „, Országmárkázás - Versenyképes identitás és imázs teremtése” címü legújabb könyve, amely az Akadémiai Kiadó gondozásában jelent meg, a Marketing Szakkönyvtár részeként.

A mű legnagyobb értéke abban van, hogy magyar nyelven kétségtelenül hiánypótló írás az országmárkázás területén; tanulmányok, cikkek és dolgozatok sora foglalkozik országmárkázással, ilyen átfogó, de erre a területi egységre fókuszált munkából mindezidáig egyik sem tudott táplálkozni, nem beszélve az aktualitás fontosságáról ebben a témában (is). A Szerző, stílusához hűen, rendkívül olvasmányos, lendületes, és a globalizáció korában megfelelően nemzetiközi jellegü írást ad az Olvasó kezébe, több mint 20 oldalas hivatkozáslistája mély elméleti alapokat nyújt, megjelenítve a releváns hazai és nemzetközi szerzőket, a számtalan aktuális, a mindennapjainkból is ismert példa pedig a megértést segíti és a gyakorlati alkalmazás lehetőségét vetíti előre.

A nagyjából 200 oldalas könyv tisztázza a márka és a márkázás alapjait, majd rámutat az országmákázás megközelítéseire és aktualitására, céljaira és sajátosságaira. Két külön fejezetben hívja fel a figyelmet az országimázs és országmárka külső és belső aspektusaira, bemutatja azt az interdiszciplináris jelleget, amely igazán komplex-szé teszi a területet, egyúttal kihívások elé állítja a vele foglalkozókat. Összegyüjti és ismerteti az országmárka értékének megközelítéseit és rangsorait, ezzel közelebb jutva a praktikus alkalmazási területekhez. A gyakorlati implikációt segítendő bemutatja az országmárkázás stratégiai hátterét, rendszerét és a stratégia megvalósítását, nem titkolva a korlátokat és a tevékenység mérhetetlen összetettségét, amellett, hogy nyilván ezek a fejezetek emelik ki a leginkább a tudatos építkezés fontosságát. Hiszen az országmárkázás természetesen egyúttal jó országépítés is kell, hogy legyen, ehhez kapunk egyfajta útmutatót a könyv által. Amellett, hogy a Szerző egymásra építkező, átlátható és összefüggésekre rámutató rendszerbe helyezi az elméleti modelleket és a kapcsolódó tudástárat, mindvégig gyakorlati példákkal illusztrálja mondandóját, számtalan aha-élményt okozva az Olvasónak és kitágítva mindannyiunk ilyen irányú gondolkodásmódját. Mindezeket egy best practice esettanulmánnyal is megerősíti, egy különálló fejezetet szentel Észtország márkázásának, amely példát mutathat minden ország, köztük Magyarország számára is.

A szakkönyvet a téma egyik legnagyobb hazai szakértője írta. A Szerző a kétezres évek eleje óta foglalkozik az országmárkázással, a terület kiemelkedő szakembere, ahogy a marketing szakmáé is, széleskörü hazai és nemzetközi oktatói, kutatói, szakmai ismereteiről és tapasztalatairól tanúskodik ez a kétségtelenül óriási munka eredményeként született szakkönyv. Struktúrája és az ismeretanyagok felépítése, valamint a fiatalos, követhetö és dinamikus jellege alkalmassá teszi az oktatásban való hasznosításra, de nagymértékben támaszkodhat rá minden országmárkával és országimázzsal foglalkozó kutató vagy épp szakdolgozó, disszertációját író, aki a könyv megjelenése előtt küzdött az országmarketing-szakirodalom fragmentáltságával. Nem utolsó sorban, a példákkal tarkított, lényegre törő stílusú tudományos mű inspiráló lehet ezek mellett minden jelenlegi és potenciális gyakorlati szakember számára is, nem csak a marketing területén.

Nyugodt szívvel ajánlom Mindenkinek, aki szélesítené ilyen irányú ismereteit, vagy csak elmélyülne az országmárkázás élményében.

Gerdesics Viktória

Pécsi Tudományegyetem 